How can the law in England and Wales be reformed In order to regulate offensive online communications with the respect to the right of freedom of expression?

Reforming the language

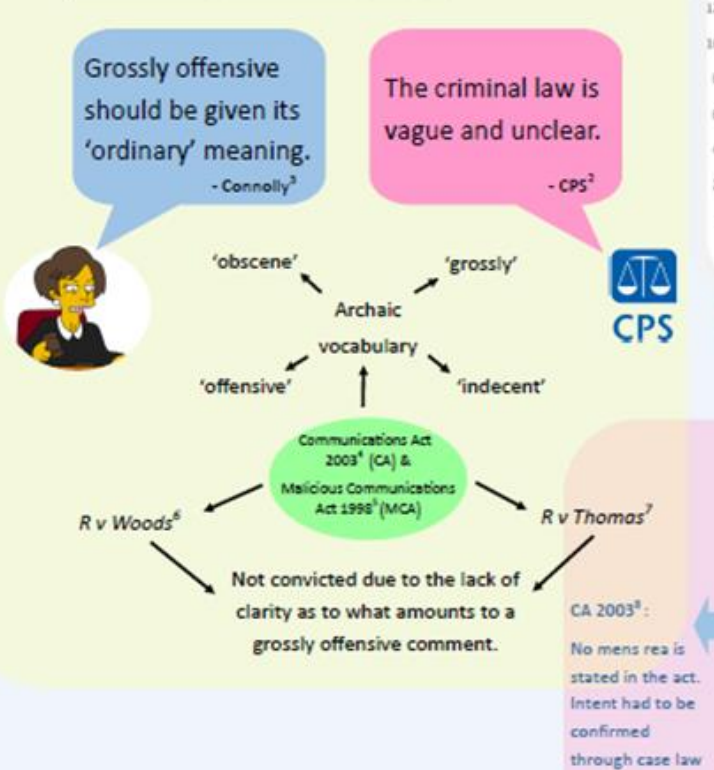

Freedom of Expression

"Freedom to hold opinions and to receive and impart information and ideas without interference by public authority and regardess of frontiers

(4)

$$
\text { -Artice } 10 \text { of ECHR" }
$$

In the case of Chabloz it was illustrated the right to freedom of expression is a qualified right and is not absolute. ${ }^{2}$

In Collins, the defendant tried to use Article 10 as a defence but was unsuccessful as the need to protect pub
safety overruled the qualified right.

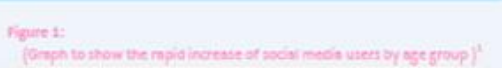

Social Networking by Age Group

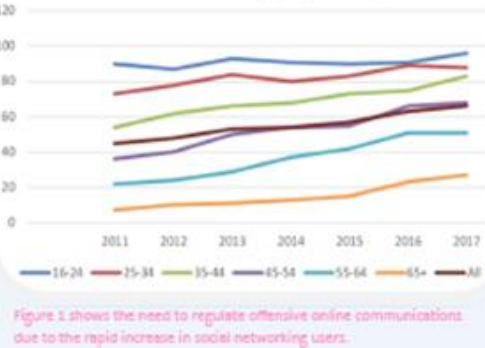

Mens rea elements

The mens rea in the MCA 1998 should be able to narrow down the intentionally broad actus reus.

The mens rea in the CA 2003 allows private conversations to still occur which are grossly offensive. Chara Bakalis

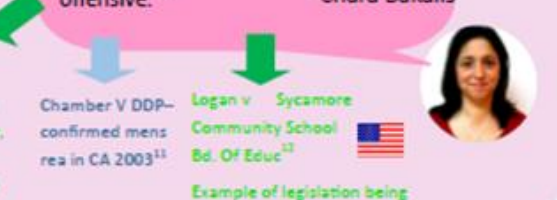
tumpled of

Our suggestions for reform

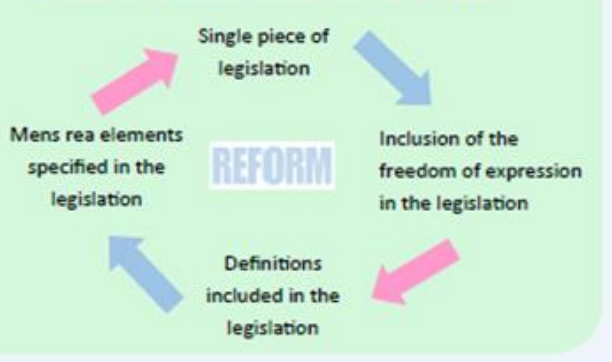




\section{How can the law in}

England and Wales be reformed in order to regulate offensive online communications with respect to the right of freedom of expression?

WORD COUNT: 2496

ESTELLE CHAMBERS, LAURA CARR, CHARLOTTE BUSHBY, REBECCA EVERSON, SARAH CURRAN, JASKARAN CHATHA 


\section{Volume 1 Issue 1 Student Journal of Professional Practice and Academic Research}

\section{Introduction}

The evolution of social media in recent years has significantly changed the way society interacts and engages with each other. Research has shown that there has been a $21 \%$ increase in social media usage by UK adults from 2011 to $2017^{1}$. This drastic shift regarding the way we communicate can be said to bring many benefits; however, it can also impose serious legal issues. Such legal issues include 'revenge porn', online blackmail and 'trolling'. For the purpose of this investigation, the main focus of the research will be on the area of offensive online communications.

The investigation will cover the effectiveness of the current criminal law in terms of offensive online communications. In addition to this, the research will be highlighting any gaps within the current law in regard to overcoming this problem. When considering potential reforms, the right to freedom of expression will remain at the forefront of the research to prevent any alienation of human rights.

\section{How is the existing language in the Communications Act 2003 and the Malicious Communications Act 1988 in need of reform?}

Many legal writers and official bodies such as the Law Commission and the Crown Prosecution Service (CPS) have acknowledged the problems the archaic nature of the Malicious Communications Act $1988^{2}$ and the Communications Act $2003^{3}$ create in criminalising offensive online communications. This concern has heightened recently as more people access social media ${ }^{4}$. Despite this, there has been no statutory reform and instead judges and the CPS are left to interpret the ambiguous and outdated terms in the Acts. This suggests the law is 'fragmented' ${ }^{5}$, due to the 'scattergun' approach used by parliament when creating the law. Academics across the field agree that this is a highly relevant issue as an increasing number of

\footnotetext{
${ }^{1}$ Office for national statistics, 'Social Networking by age group, 2011 to 2017' (Office for National Statistics, 24 August

<https://www.ons.gov.uk/peoplepopulationandcommunity/householdcharacteristics/homeinternetandsocialmedi ausage/adhocs/007401socialnetworkingbyagegroup2011to2017> accessed 6 November 2018

${ }^{2}$ Malicious Communications Act 1998, s.1

${ }^{3}$ Communications Act 2003, s.127

${ }^{4}$ n.1 Refer back to the statistics stated in the introduction

${ }^{5}$ Chara Bakalis, "Rethinking cyberhate laws” (2017) 27(1) Information \& Communications Technology Law 86110
} 


\section{Volume 1 Issue 1 Student Journal of Professional Practice and Academic Research}

defendants are self-represented and inappropriate technical and obsolete language only further alienates the public from our system, which damages the profession. ${ }^{6}$

In their 2013 guidelines on 'Prosecuting cases involving communications sent via social media' ${ }^{7}$, the CPS stress the need to interpret the meaning of terms such as 'grossly offensive' in compliance with the right to freedom of expression. It was decided in Connolly $v$ $D P P^{8}$ that 'grossly' should be given its 'ordinary' ${ }^{9}$ meaning, as well as words included in the 2003 act such as 'indecent' and 'obscene'. Although the courts declared this, there remains an element of ambiguity in what the 'ordinary' meaning is. Considering the context of the acts, with the 1988 Act created for postal communications and the 2003 Act for broadcasts, it is questionable whether the ordinary meaning of grossly offensive remains the same in relation to the internet and social media or whether the standard differs. Furthermore, this lack of clarity means it can never be clear when a comment said online crosses the line from being 'merely offensive' 10 to something that is 'so grossly offensive it should be criminalised" ${ }^{11}$ meaning there is a lack of certainty in the law.

Although the CPS have attempted to improve this understanding it remains questionable whether it is effective in practice, with many academic writers including Laura Bliss, as well as the Law Commission, criticising the current law. This is shown through the different outcomes of cases such as the unreported case of $R v$ Woods in $2012^{12}$ when the defendant made comments online about missing April Jones, and the homophobic comments made by the defendant in Thomas $^{13}$. Thomas was not convicted which emphasises the lack of clarity as to 'what amounts to a grossly offensive comment' 14 .

It seems apparent that reform of the law on offensive communications is necessary to be effective in modern society, with many arguing that 'guidelines are no substitute for clearer

\footnotetext{
${ }^{6}$ Alexandra-Maria Eugenicos, 'Should we reform the Offences Against the Person Act 1861?' (2017) 81(1) Journal of Criminal Law

${ }^{7}$ Crown Prosecution Service, "Social Media - Guidelines on prosecuting cases involving communications sent via social media” (revised 21 August 2018)

${ }^{8}$ Connolly v DPP (2007) EWHC 237; (2008) 1 W.L.R. 276

${ }^{9}$ Ibid [3]

${ }^{10}$ Laura Bliss, “The crown Prosecution guidelines and grossly offensive comments: an analysis” (2017) 9(2) Journal of Media Law 173-188

11 ibid

${ }^{12} R v$ Woods case stated in n.10

${ }^{13} R v$ Thomas case stated in n.10

${ }^{14}$ n. 10
} 


\section{Volume 1 Issue 1 Student Journal of Professional Practice and Academic Research}

law $^{15}$. The Law Commission has for years encouraged the codification of the criminal law ${ }^{16}$, describing it as 'vague and unclear' ${ }^{17}$.

\section{Are the mens rea elements clear in the Malicious Communications Act 1988 and the} Communications Act 2003?

For a defendant to be prosecuted of an offensive online communication, the mens rea element of intention must be proven. In criminal cases, the concept of intention can be described in two distinct ways through the clarification in cases. Firstly, as oblique intent; this is where the consequence of the defendant's action is "virtually certain" ${ }^{18}$. Secondly as direct intent, meaning the defendant wants to complete a desired aim or purpose ${ }^{19}$.

In addition to this, offences can be described as either a basic intent crime or a specific intent crime. Like these previous concepts of intention, these terms have been defined using common law. The main difference between the two is crimes which only have the mens rea as intention is of specific intent, whereas the mens rea could be recklessness, which is " $\mathrm{D}$ taking an unjustifiable risk of a particular consequence occurring” ${ }^{20}$ or intention for basic intent crimes. $^{21}$

The issue surrounding the mens rea elements in the Malicious Communications Act $1988^{22}$ and the Communications Act $2003^{23}$ is that the meaning is unclear. In the Malicious Communications Act, it is stated that the defendant must have the intention to "cause distress or anxiety" ${ }^{24}$ when sending an online communication. This idea is confirmed in Chambers ${ }^{25}$, in which the defendant must have "acted with a specific purpose in mind" 26 . Therefore, it must be proven that the defendant is trying to send the communication with the thought of the recipient being disturbed by the message. Even if the person does not feel this way, the

\footnotetext{
${ }^{15}$ Kat Shields and Katie Jones, “Tackling online trolling” (2016) 180(37) Criminal Law \& Justice Weekly

16 Mary Arden, 'Criminal law at the crossroads: the impact of human rights from the Law Commission's perspective and the need for a code' (1999] 1(1) Criminal Law Review

${ }^{17}$ Law Commission, “Abusive and Offensive Online Communications: A Scoping Report” (Law Com No 381, 2018) 113, para 5.95

${ }^{18} R$ v Nedrick [1986] 3 All ER 47 - Case was used to provide a test for a distinction between direct intent and oblique intent

${ }^{19}$ Tony Storey, Unlocking Criminal Law (6 edn, Routledge 2017) 62

${ }^{20}$ Ibid 67

${ }^{21}$ Ibid 296

${ }^{22} \mathrm{n} .2$

${ }^{23} \mathrm{n} .3$

${ }^{24} \mathrm{n} .2$ [s.1(1b)]

${ }^{25}$ DDP v Chambers [2012] EWHC 2157

26 ibid [36]
} 


\section{Volume 1 Issue 1 Student Journal of Professional Practice and Academic Research}

defendant could still be charged, as "the sender of the grossly offensive message must intend it to cause distress or anxiety to its immediate or eventual recipient”27, thus making it not a 'constitutional element ${ }^{\text {, }}{ }^{28}$ of the crime. However in the relevant section of the Communications $\mathrm{Act}^{29}$, it does not mention intention at all. Therefore, in Collins ${ }^{30}$, it needed to be clarified that intent was a necessary mens rea element.

Despite both acts needing intention to be a necessary mens rea element, the intention is different in each act. Chambers mentions the Malicious Communications Act is "a specific intent [crime, whilst] no express provision is made in [the Communications Act] section 127(1)(a) for mens rea. It is therefore an offence of basic intent." ${ }^{31}$ This suggests that recklessness can be a contributing factor, to be charged under the communications act, which is not stated in the statute like 'intention' is. By clearly stating this, it can help distinguish what offences can be charged under which act as there is much confusion due to the overlap of the two. Additionally, as there is some distinction between the two intents through the common law, it can be argued that the Malicious Communication Act requires direct intent because the 'intention' is necessary for a crime to occur. Furthermore, oblique intent is the element in the Communications Act as recklessness can be in the mens rea.

Academic Chara Bakalis discusses the consequences of the mens rea elements of both acts in detail. When discussing the mens rea for the Malicious Communications Act, Bakalis highlights that the actus reus is broad, and for the act to be concise, the mens rea needs to be able to narrow this down. Nevertheless, due to the mens rea being intention, it does not correctly limit the offence, as a defendant can just state that they did not mean to create "distress or anxiety”. Therefore, the Malicious Communications Act is not fulfilling its aim, when it comes to regulating online communications. Furthermore, Bakalis discusses the importance of the mens rea element in the Communications Act, by using an example of an "online but private conversation of two racists on holocaust denial as the discussion could plausibly be characterised as 'grossly offensive'”32. As the conversation was private and the comments were not used to create disgust amongst a wider audience, this would not be a crime as the mens rea

\footnotetext{
${ }^{27}$ Collins v DDP [2006] 1 WLR 2223 (UKHL) [26]

${ }^{28} \mathrm{Q}$ Hunt, 'Striking a balance - Malicious Communication Act and free speech' (Criminal Defence Barrister Blog, 28 May) <http://www.bestcriminaldefencebarrister.co.uk/criminal-defence-barrister-blog/2018/striking-abalance-malicious-communication-act-and-free-speech.aspx> accessed 14 November 2018

$29 \mathrm{n} .2$

30 n. 27

31 n.25 [36]

32 n. 5
} 


\section{Volume 1 Issue 1 Student Journal of Professional Practice and Academic Research}

would not be present. ${ }^{33}$ This illustrates the need for a clearer definition of the mens rea element within the legislation, which could withstand evolution of social media.

Finally, the need to prove intention could become difficult in the essence of online communication cases, involving children and young adults. It is already hard to prove intention, but it becomes more difficult if a serious crime occurs and the person prosecuted is not fully capable of understanding words that "cause distress or anxiety" 34 . Many young people use offensive language online towards other individuals, due to the accessibility of social media ${ }^{35}$. One case which highlights this, which occurred in America, was Logan v Sycamore Community $\mathrm{School}^{36}$. From this case it can be determined that it is difficult to judge whether the defendants intended to say those words in an offensive manner, as they were young adults. The case was settled and led to the "Jessica Logan Act”, being implemented into Ohio state law ${ }^{37}$. This law revises the laws within schools regarding harassment through an electronic act. In areas of the world which online offensive communications are also a major issue, legislation is being introduced to adjust with the advances to prevent situations like the example from occurring. This, however, is not occurring in England and Wales and shows that reforms regarding the mens rea, are urgent, primarily due to the last update being in 2003.

\section{Will reforming the law restrict freedom of expression?}

Although many academic writers state that current legislation needs to be reformed, a possible reason why this has not occurred is the fear of breaching the freedom of expresson. The freedom of expression proposed by Article 10 of the European Convention on Human Rights ${ }^{38}$ is protected by common law and is arguably one of the most important fundamental freedoms that stabilises democratic society. This includes the 'freedom to hold opinions and to receive and impart information and ideas without interference by public authority and regardless of frontiers, $^{39}$.

\footnotetext{
33 ibid

${ }^{34} \mathrm{n} .2$

${ }^{35}$ D Watkins, 'Where do I stand? Assessing children's capabilities under English law' (2016) 28(1) Child and Family Law Quarterly 25-44

${ }^{36}$ Logan v. Sycamore Community School Bd. Of Educ., 780 F. Supp. 2d 594 (S.D. Ohio 2011) - facts of this case can be found in the judgement

37 Substitute House Bill Number 116, 129 ${ }^{\text {th }}$ General Assembly, (Ohio 2012)

${ }^{38}$ Convention for the Protection of Human Rights and Fundamental Freedoms, Article 10

${ }^{39}$ Human Rights Act 1998 Article 10 s 1
} 


\section{Volume 1 Issue 1 Student Journal of Professional Practice and Academic Research}

Although the act exercises that this right is universal, meaning it applies to everyone, there are however restrictions which are executed by the law. These restrictions 'are necessary in a democratic society, in the interests of national security, territorial integrity or public safety, for the prevention of disorder or crime. ${ }^{40}$ When trying to justify the freedom of expression, numerous factors are to be considered. For example, these may include 'the identity of the speaker, the context of the speech and its purpose, as well as the actual words spoken or written'. ${ }^{41}$

Regarding the Malicious Communications Act a person will therefore be found guilty if they send 'any letter, email, photograph or recording which is indecent, grossly offensive or which conveys a threat is an offence if the sender intends to cause distress or anxiety to the recipient' ${ }^{42}$. Once convicted under this act it could be said that an individual's right to the freedom to expression was breached. However, it is important to note that Article 10 of the Human Rights Act is a 'qualified right' meaning that it is used in proportion within society to achieve its telos.

The same principle applies under the Communications Act 2003. The case of $R v$ Chabloz $^{43}$ can be used to illustrate how the freedom of expression can somewhat be limited when meeting the demands of the law. The Defendant in this case made several anti-Semitic comments online. Prosecuted under s.127, Chabloz attempted to use Article 10 as her defence which 'illustrate(s) the continued difficulties the criminal justice system experiences ${ }^{34}$ in understanding when the law should limit an individual's freedom of expression. Article 10 is not an absolute right and can be restricted if certain criteria are met but it remains unclear as to when the law should intervene.

A specific case, similar to Chabloz, is Collins, as mentioned prior. This case involved a man who made several phone calls to Westminster offices. 'In these telephone calls and recorded messages the respondent, who held strong views on immigration and asylum policy and the provision of public support to immigrants and applicants for asylum, ranted and shouted and made reference to "Wogs", "Pakis", "Black bastards" and (according to the

\footnotetext{
40 ibid ss. 2

41 'Freedom of expression Legal Framework' (Equality and Human Rights Commission, 25th May 2016) $<$ https://www.equalityhumanrights.com/sites/default/files/20150318_foe_legal_framework_guidance_revised_fi nal.pdf $>$ accessed 14 November 2018

42 n.2

${ }^{43} R$ v Chabloz case cited in article "Social Media; 'A theme park just for fools' - R v Alison Chabloz” (n.44)

${ }^{44}$ Laura Bliss, "Social Media; 'A theme park just for fools’ - R v Alison Chabloz” (2018) J. Crim. L. 82(4), 301304
} 


\section{Volume 1 Issue 1 Student Journal of Professional Practice and Academic Research}

statement of facts agreed between the parties for purposes of this appeal but not the case stated by the Justices) "Niggers"45. When prosecuted, he tried to use Article 10 to his defence, but was unsuccessful because the need to protect public safety overruled the qualified right to freedom of expression.

If the Malicious Communications Act and the Communications Act are to be reformed, there needs to be clarity in what is deemed freedom of expression and offensive language. Academics such as Chara Bakalis reiterates this as she states "the underlying purpose of each piece of legislation will need to be articulated and subsequently examined to determine whether the mischief it is protecting does indeed fall into the Article 10(2) exceptions." ${ }^{46}$ As freedom of expression is such a fundamental right, it should always be considered in order to stabilise a democratic society.

\section{Conclusion}

After careful consideration and extensive research on this topic, it is clear that reforms are necessary in order to codify and consolidate the law. As a result, this will help regulate offensive online communications.

A way that could be suggested to consolidate the law would be to combine the relevant areas of the two existing Acts to create a single piece of legislation. This would make the law regarding offensive online communications more accessible. Therefore, removing the 'scattergun' approach used by parliament when creating the current law, making it easier to prosecute in future. However, this single piece of legislation could prove to be too narrow as it has the potential to brush over significant parts of the two existing Acts. To prevent this, a significant amount of time should be allocated reviewing the proposed reform.

As well as consolidating the law, codification of the law is also necessary. This would relate to the use of archaic vocabulary in the current legislation, such as 'grossly offensive' and 'obscene'. The use of these words is outdated in modern society. To update the law, more articulated vocabulary should replace the archaic phrasing used previously, with definitions included in the reformed Act.

\footnotetext{
45 n.27 [40]

${ }^{46} \mathrm{n} .5$
} 


\section{Volume 1 Issue 1 Student Journal of Professional Practice and Academic Research}

Another important element to consider is the transparency of the mens rea in the reformed legislation. For the two separate offences, intention and/or recklessness should be clearly specified. The new law should try to identify what actions, or lack of them, would determine the culpability of the crime.

The freedom of expression should not be ignored when reforming this law, as it is vital to human rights. A clear distinction should be made in order to clarify when an expression becomes a criminal offence. The inclusion of this right in the reformed law should highlight key aspects of the human rights act, making it clear when offensive online communications is no longer an opinion, but a criminal act.

With the suggested reforms taken into consideration, it is likely that it will become easier to regulate offensive online communications with respect to the freedom of expression. 
Volume 1 Issue 1 Student Journal of Professional Practice and Academic Research

\section{Bibliography}

Table of cases

$\underline{\text { UK Jurisdiction }}$

Chambers v DDP [2012] EWHC 2157

Collins v DDP [2006] 1 W.L.R 2223 UKHL

Connolly v DDP [2007] EWHC 237; [2008] 1 W.L.R 276

Nedrick v R [1986] 3 All ER 47

\section{Other Jurisdiction}

Logan v. Sycamore Community School Bd. Of Educ., 780 F. Supp. 2d 594 (S.D. Ohio 2011)

Table of Legislation

$\underline{\text { UK Jurisdiction }}$

Communications Act 2003

Human Rights Act 1998

Malicious Communications Act 1988

\section{European treaties}

Convention for the Protection of Human Rights and Fundamental Freedoms

Other Jurisdiction

Substitute House Bill Number 116, 129th General Assembly, (Ohio 2012)

\section{Secondary Sources}

Articles

Arden M, 'Criminal law at the crossroads: the impact of human rights from the Law Commission's perspective and the need for a code' [1999] 1(1) Criminal Law Review

Bakalis C, "Rethinking cyberhate laws" (2017) Information \& Communications Technology Law, 27(1) 86-110 
Volume 1 Issue 1 Student Journal of Professional Practice and Academic Research

Bliss L, "Social Media; 'A theme park just for fools' - R v Alison Chabloz" (2018) J. Crim. L. 82(4), 301-304

Bliss L, "The Crown Prosecution guidelines and grossly offensive comments: an analysis" (2017) Journal of Media Law 9(2), 173-188

Eugenicos AM, 'Should we reform the Offences against the Person Act 1861?' [2017] 81(1) Journal of Criminal Law

Shields K and Jones K, "Tackling online trolling" (2016) Criminal Law \& Justice Weekly 180(37)

Watkins D, 'Where do I stand? Assessing children's capabilities under English law' [2016] 28(1) Child and Family Law Quarterly 25-44

Books

Storey T, Unlocking Criminal Law (6 edn, Routledge 2017)

Reports

Crown Prosecution Service, "Social Media - Guidelines on prosecuting cases involving communications sent via social media" (revised 21 August 2018)

'Freedom of expression Legal Framework' (Equality and Human Rights Commission, 25th May 2016)

< https://www.equalityhumanrights.com/sites/default/files/20150318 foe legal framewor $\underline{k}$ guidance revised final.pdf> accessed 14 November 2018

Law Commission, "Abusive and Offensive Online Communications: A Scoping Report" (Law Com No 381, 2018) 113, para 5.95

Office for national statistics, 'Social Networking by age group, 2011 to 2017' (Office for National Statistics, 24 August 2017) <https://www.ons.gov.uk/peoplepopulationandcommunity/householdcharacteristics/home 
Volume 1 Issue 1 Student Journal of Professional Practice and Academic Research

internetandsocialmediausage/adhocs/007401socialnetworkingbyagegroup2011to2017> accessed 6 November 2018

Websites and Blogs

Hunt Q, 'Striking a balance - Malicious Communication Act and free speech' (Criminal

Defence Barrister Blog, 28 May) http://www.bestcriminaldefencebarrister.co.uk/criminaldefence-barrister-blog/2018/striking-a-balance-malicious-communication-act-and-freespeech.aspx accessed 14 November 2018 